\title{
Penurunan Kadar Laktat pada Pemberian Norepinefrin dengan Plasebo dan Norepinefrin dengan Adjuvan Vasopresin pada Pasien Syok Septik
}

\author{
Metty Savitri, Asmin Lubis, Chairul Mursin \\ Departemen Anestesiologi dan Terapi Intensif Fakultas Kedokteran Universitas Sumatera Utara \\ RSUP Haji Adam Malik Medan
}

\begin{abstract}
Abstrak
Laktat merupakan faktor prognostik yang digunakan sebagai indikator beratnya keadaan syok septik dan mortalitas. Vasopresor merupakan obat yang dibutuhkan untuk menjaga tekanan perfusi pada hipotensi berat, untuk mencapai hemodinamik yang diinginkan seperti tekanan vena sentral, MAP, pengeluaran urin, dan oksigenasi. Beberapa penelitian menunjukkan penurunan kadar laktat terhadap pemberian norepinefrin dan vasopresin. Penelitian ini menggunakan desain uji double blind, randomized controlled control trial yang dilakukan pada bulan Desember 2016 sampai Februari 2017 di RSUP Haji Adam Malik Medan. Empat puluh pasien syok septik yang memenuhi kriteria inklusi dan tidak termasuk kriteria eksklusi dibagi 2 kelompok, yaitu kelompok yang mendapat norepinefrin dengan plasebo dan kelompok yang mendapat norepinefrin dengan vasopresin. Kadar laktat dinilai pada kedua kelompok pada waktu setelah pemberian $30 \mathrm{~mL} / \mathrm{kgBB}$, setelah MAP tercapai target $65 \mathrm{mmHg}$ dengan pemberian norepinefrin, dan 6 jam setelah perlakuan dengan plasebo atau vasopresin. Hasil penelitian menunjukkan kadar laktat pada plasebo dan vasopresin setelah pemberian $30 \mathrm{~mL} / \mathrm{kgBB}$, setelah MAP tercapai target $65 \mathrm{mmHg}$ dengan pemberian norepinefrin, dan 6 jam setelah perlakuan didapatkan penurunan kadar laktat yang bermakna $(p<0,05)$. Uji beda penurunan kadar laktat antara plasebo dengan vasopresin didapatkan hasil yang tidak bermakna pada tiga kali pengukuran $(\mathrm{p} \geq 0,05)$. Simpulan, tidak terdapat perbedaan antara plasebo dan vasopresin terhadap penurunan kadar laktat.
\end{abstract}

Kata kunci: Kadar laktat, norepinefrin, syok septik, vasopresin

\section{Lactate Level Decrease in Norepinephrine-Placebo Versus Norepinephrine- Adjuvant Vasopressin Administration in Patients with Septic Shock}

\begin{abstract}
Lactate is a prognostic factor used as an indicator for severity and mortality of septic shock. Vasopressor is a medication used to maintain perfusion pressure in severe hypotension to reach the hemodynamic demand such as the demand for central venous pressure, MAP, urine output, and oxygenation. Many studies show that there is a decrease in lactate amount after the administration of norepinephrine and vasopressin. This study was a double blind, randomized controlled trial during the period of December 2016-February 2017 on forty septic shock patients in Haji Adam Malik General Hospital who are eligible for the study. Patients were divided into 2 groups: placebo group (A) and vasopressin group (B). Lactate level was checked after the administration of norepinephrine $30 \mathrm{~mL} / \mathrm{kgBW}$, after the MAP reached $65 \mathrm{mmHg}$, and 6 hours after the administration of placebo and vasopressin. There was a decrease in lactate level $(p<0.05)$ after the administration of norepinephrine with placebo and vasopressin, after the administration of norepinephrine when the MAP reached $65 \mathrm{mmHg}$, and 6 hours after treatment. The difference in lactate levels between placebo and vasopressin groups swas not significant in all three measurements $(p \geq 0.05)$. There was no significant difference between the norephinephrine and placebo with norephinephrine and vasopressin adjuvant.
\end{abstract}

Key words: Norepinephrine, vasopressin, lactate level, septic shock

Korespondensi: Metty Savitri, dr., SpAn, Departemen Anestesiologi dan Terapi Intensif, Fakultas Kedokteran Universitas Sumatera Utara, RSUD Haji Adam Malik Medan, Jl. Bunga Lau No. 17, Kemenangan Tani, Medan, Sumatera Utara 20136, Tlpn 061-8362080,Email metty.savitri.an@gmail.com 


\section{Pendahuluan}

Laktat merupakan faktor prognostik yang digunakan sebagai indikator beratnya keadaan syok ditandai degan terjadinya hipoperfusi jaringan karena kekurangan oksigen akan menyebabkan glukosa dimetabolisme pada kondisi anaerobik sehingga sel akan mengubah piruvat menjadi laktat. ${ }^{1,2}$

Pembersihan laktat mempunyai hubungan dengan perbaikan tingkat mortalitas dan morbiditas. Pembersihan laktat mulai dimasukkan ke dalam surviving sepsis campaign (SSC) karena memberikan hasil yang signifikan dalam hal pengurangan mortalitas, hampir mencapai 2 kali lipat dari pengurangan angka kematian. ${ }^{3,4}$

Suatu penelitian yang membandingkan pemberian monoterapi norepinefrin dengan kombinasi norepinefrin dan vasopresin, hasil penelitian menunjukkan dosis penggunaan norepinefrin berkurang dan diperoleh MAP yang lebih tinggi serta denyut nadi yang lebih rendah. Pemberian vasopresin dosis rendah menunjukkan hasil pembersihan laktat (lactate clearance) yang signifikan dikarenakan vasopresin memberikan efek pada mikrosirkulasi dan sparing effect katekolamin. $^{5}$

Penelitian lain meunjukkan pemberian vasopresin dan analognya dapat menurunkan tingkat mortalitas secara signifikan pada pasien dengan syok septik, sedangkan dalam hal kadar laktat tidak terdapat perbedaan yang signifikan. ${ }^{6,7}$

Pemberian vasopresin dosis rendah tidak menurunkan angka mortalitas bila dibanding dengan norepinefrin pada pasien syok septik pada hari ke-28 dan hari ke-90, namun menurunkan angka kematian pada pasien sepsis syok ringan pada hari ke-28 dan hari ke-90 serta tidak terdapat perbedaan kadar laktat serum antara kedua kelompok. Terdapat perbedaan kadar laktat serum yang cukup signifikan $(\mathrm{p}<0,05)$ yang menunjukkan keunggulan vasopresin pada pasien syok. ${ }^{8,9}$

Sebuah penelitian lain menyatakan bahwa tidak ada data yang cukup untuk membuktikan bahwa norepinefrin lebih bagus daripada vasopresin dalam hal mortalitas dan hemodinamik. Berdasar atas penelitian terhadap 2.323 pasien syok septik yang dibanding dengan penggunaan norepinefrin dengan vasopresin, ternyata angka mortalitas pasien yang menggunakan norepinefrin tidak jauh berbeda dibanding dengan yang diberikan vasopresin. ${ }^{10,11}$

Penelitian lain menunjukkan bahwa vasopresin tidak lebih buruk dibanding dengan norepinefrin. Penggunaan vasopresin akan lebih cepat meningkatkan MAP daripada menggunakan norepinefrin tunggal dan nilai laktat pada kelompok vasopresin mengalami perbaikan yang lebih baik dibanding dengan norepinefrin pada jam ke-6 resusitasi. ${ }^{12,13}$

Berdasar atas beberapa uraian dan penelitian di atas maka peneliti tertarik melakukan penelitian pemberian norepinefrin ditambah plasebo dibanding dengan pemberian norepinefrin ditambah vasopresin terhadap perubahan laktat pada pasien syok septik.

\section{Subjek dan Metode}

Penelitian ini menggunakan desain uji double blind, randomized controlled clinical trial untuk menilai perbedaan penurunan kadar laktat pada pemberian norepinefrin dengan plasebo dan norepinefrin dengan adjuvan vasopresin pada pasien syok septik. Populasi dalam penelitian ini adalah pasien dengan syok septik yang dirawat di RSUP H. Adam Malik Medan. Sampel penelitian diambil dari seluruh pasien dewasa dengan syok sepsis yang dirawat di RSUP H. Adam Malik Medan yang memenuhi kriteria inklusi dan tidak termasuk kriteria eksklusi. Kriteria inklusi penelitian ini adalah pasien usia dewasa 19 tahun sampai 60 tahun, pasien yang sudah diresusitasi cairan sebelumnya, dan tidak ada respons terhadap hemodinamik. Kriteria eksklusi penelitian ini adalah hamil, keganasan, kelainan jantung kongenital, dan kelainan katup jantung.

Perhitungan besar sampel minimal dengan menggunakan rumus besar sampel untuk uji hipotesis terhadap rata-rata dua populasi dalam dua kelompok independen didapatkan 
jumlah sampel adalah 40 orang. Sampel yang telah memenuhi kriteria inklusi dan tidak termasuk eksklusi dibagi secara random menjadi 2 kelompok intervensi (perlakuan). Kelompok norepinefrin dengan plasebo: norepinefrin $(0,05-1 \mathrm{mcg} / \mathrm{kgBB})+$ plasebo (Nacl 0,9\% $50 \mathrm{~mL}$ ), kelompok norepinefrin dengan vasopresin: norepinefrin $(0,05-1 \mathrm{mcg} /$ $\mathrm{kgBB})+$ vasopresin $(0,01-0,03$ unit/menit). Pasien syok septik tetap mendapat perawatan dan pengobatan yang sama sesuai dengan pedoman praktik klinis RSUP Haji Adam Malik.

Semua sampel dilakukan pemeriksaan fisis dan pemeriksaan penunjang. Sampel dibagi secara random menjadi dua kelompok, yaitu kelompok A dan B mendapatkan norepinefrin $(0,5-1 \mathrm{mcg} / \mathrm{kgBB} / \mathrm{menit})$ dititrasi dari 0,05 $\mathrm{mcg} / \mathrm{kgBB}$ sampai mencapai target MAP $\geq$ $65 \mathrm{mmHg}$. Setelah target MAP $\geq 65 \mathrm{mmHg}$, maka dilakukan pemeriksaan laktat pada kelompok norepinefrin dengan plasebo dan kelompok norepinefrin dengan vasopresin. Setelah kelompok norepinefrin dengan plasebo dan kelompok norepinefrin dengan vasopresin. mencapai target $\mathrm{MAP} \geq 65 \mathrm{mmHg}$ kemudian kelompok norepinefrin dengan plasebo diberikan plasebo yang berupa $\mathrm{NaCl}$ 0,9\% sebanyak 1,5 mL/jam dan kelompok norepinefrin dengan vasopresin diberi vasopresin $1,5 \mathrm{~mL} / \mathrm{jam}(0,01 \mathrm{unit} / \mathrm{menit})$.

Setelah 6 jam pemberian vasopresin atau plasebo dari kelompok norepinefrin dengan plasebo dan kelompok norepinefrin dengan vasopresin, dilakukan pemeriksaan laktat pada setiap kelompok. Setelah data yang diperlukan telah terkumpul, data tersebut diperiksa kembali tentang kelengkapannya sebelum ditabulasi dan diolah. Data tersebut diolah menggunakan perangkat lunak SPSS 23. Data dikatakan berdistribusi normal jika nilai $\mathrm{p} \geq 0,05$ setelah dianalisis menggunakan uji Shapiro-Wilk. Batas kemaknaan yang diambil $\mathrm{p}<0,05$ dengan interval kepercayaan $95 \%$.

\section{Hasil}

Penelitian diikuti oleh 40 subjek yang dibagi menjadi dua kelompok dengan jumlah yang

\section{Tabel 1 Karakteristik Demografi Subjek}

\begin{tabular}{lccc}
\hline & \multicolumn{2}{c}{ Kelompok } & \\
\cline { 2 - 3 } & $\begin{array}{c}\text { Kelompok Norepinefrin } \\
\text { dengan Plasebo } \\
\mathbf{n = 2 0}\end{array}$ & $\begin{array}{c}\text { Norepinefrin dengan } \\
\text { Vasopresin } \\
\mathbf{n = 2 0}\end{array}$ & $\mathbf{p}$ \\
\hline Jenis kelamin, n (\%) & 11 & 11 & $1,000^{\text {a }}$ \\
Laki-laki & 9 & 9 & $0,647^{\mathrm{b}}$ \\
Perempuan & $42,6(14,76)$ & $44,25(13,24)$ & $0,944^{\mathrm{c}}$ \\
Usia, rata-rata (SD), tahun & $56,75(5,92)$ & $56,4(4,10)$ & \\
Berat badan, rata-rata (SD), $\mathrm{kg}$ & & & \\
\hline
\end{tabular}

Keterangan: ${ }^{\mathrm{a}}$ chi-square, ${ }^{\mathrm{b}} \mathrm{T}$ independen, ${ }^{\mathrm{c}} \mathrm{Mann}$ Whitney

Tabel 2 Perbedaan Laktat antara Kelompok Norepinefrin dengan Plasebo dan Kelompok Norepinefrin dengan Vasopresin Sebelum dan Sesudah Terapi

\begin{tabular}{cccc}
\hline \multirow{2}{*}{ Laktat } & $\begin{array}{c}\text { Kelompok Norepinefrin dengan } \\
\text { Plasebo n = 20 }\end{array}$ & $\begin{array}{c}\text { Kelompok Norepinefrin dengan } \\
\text { Vasopresin n = 20 }\end{array}$ & \multirow{2}{*}{$\mathbf{p}^{*}$} \\
\cline { 2 - 3 } & Rata-rata (Standar Deviasi) & Rata-rata (Standar Deviasi) & \\
\hline T0 & $6,15(0,59)$ & $6,06(0,69)$ & 0,679 \\
T1 & $5,85(0,59)$ & $5,76(0,68)$ & 0,674 \\
T2 & $5,68(0,55)$ & $5,35(0,61)$ & 0,085 \\
\hline
\end{tabular}

Keterangan: ${ }^{*}$ T independen 
Tabel 3 Perbedaan Laktat Sebelum dengan Sesudah Terapi antara Kelompok Norepinefrin dan Plasebo

\begin{tabular}{ccc}
\hline Laktat & $\begin{array}{c}\text { Kelompok Norepinefrin dengan Plasebo } \\
\mathbf{n}=\mathbf{2 0} \\
\text { Rata-rata (Standar Deviasi) }\end{array}$ & p \\
\hline T0 & $6,15(0,59)$ & $<0,001$ \\
T1 & $5,85(0,59)$ & \\
T2 & $5,68(0,55)$ & \\
\hline
\end{tabular}

Keterangan: *Repeated ANOVA

Tabel 4 Perbedaan Laktat Sebelum dengan Sesudah Terapi pada Kelompok Norepinefrin dengan Vasopresin

\begin{tabular}{ccc}
\hline Laktat & $\begin{array}{c}\text { Kelompok Norepinefrin dengan Vasopresin } \\
\mathbf{n}=\mathbf{2 0} \\
\text { Rata-rata (Standar Deviasi) }\end{array}$ & p* \\
\hline T0 & $6,06(0,69)$ & $<0,001$ \\
T1 & $5,76(0,68)$ & \\
T2 & $5,35(0,71)$ & \\
\hline
\end{tabular}

Keterangan: *Repeated ANOVA

sama, yaitu masing-masing sebanyak 20 orang mendapat norepinefrin dengan plasebo dan norepinefrin dengan vasopresin. Subjek laki-laki 11 orang dan perempuan 9 orang. Tidak ada perbedaan yang signifikan pada karakteristik pasien dalam penelitian ini $(\mathrm{p} \geq$ 0,05; Tabel 1).

Hasil analisis menggunakan uji-t independen memperlihatkan bahwa tidak terdapat perbedaan kadar laktat rata-rata pada dua kelompok untuk seluruh pengamatan ( $\mathrm{p} \geq 0,05$; Tabel 2).

Berdasar atas analisis lanjutan repeated ANOVA, dapat dilihat bahwa kadar laktat rata-rata sebelum pemberian terapi (plasebo) dengan laktat rata-rata pada pengamatan kedua (T1) memiliki selisih yang signifikan. Begitu pula sebelum pemberian plasebo dengan pengamatan kedua (T2) dan antara pengamatan T1 dan T2 memiliki selisih ratarata yang signifikan $(\mathrm{p}<0,001$; Tabel 3$)$.

Berdasar atas uji lanjutan sejalan hasil penelitian pada norepinefrin dengan vasopresin, kadar laktat rata-rata antara T0 dan T1, T0, dan T2, serta T1 dan T2 memiliki selisih rata-rata yang signifikan $(\mathrm{p}<0,001$; Tabel 4).

Berdasar atas analisis data, tidak ditemukan perbedaan penurunan kadar laktat pada norepinefrin dengan plasebo

Tabel 5 Perbedaan Delta Laktat Sebelum dengan Sesudah Terapi pada Kelompok Norepinefrin dengan Plasebo dan Kelompok Norepinefrin dengan Vasopresin

\begin{tabular}{lccc}
\hline & $\begin{array}{c}\text { Kelompok Norepinefrin dengan } \\
\text { Plasebo } \mathbf{~}=\mathbf{2 0} \\
\text { Rata-rata (Standar Deviasi) }\end{array}$ & $\begin{array}{c}\text { Kelompok Norepinefrin } \\
\text { dengan Vasopresin } \mathbf{n}=\mathbf{2 0} \\
\text { Rata-rata (Standar Deviasi) }\end{array}$ & p \\
\hline Delta T0-T1 & $0,3(0)$ & $0,3(0,03)$ & 1,000 \\
Delta T0-T2 & $0,47(0,05)$ & $0,57(0,09)$ & 0,006 \\
Delta T1-T2 & $0,17(0,05)$ & $0,25(0,08)$ & 0,007 \\
\hline
\end{tabular}

Keterangan: *Mann Whitney 
dan norepinefrin dengan vasopresin antara pengamatan sebelum terapi (T0) dan kadar laktat pada pengamatan T1. Terdapat perbedaan penurunan kadar laktat rata-rata yang tidak bermakna untuk pengamatan T0 dan T2 antara dua kelompok intervensi $(\mathrm{p} \geq 0,05)$.

Nilai penurunan kadar laktat antara pengamatan T1 dan T2 juga tampak lebih besar pada kelompok norepinefrin dengan vasopresin dibanding dengan kelompok norepinefrin dengan plasebo. Namun, hasil analisis uji Mann Whitney terdapat perbedaan rata-rata yang tidak bermakna antara dua kelompok studi ( $\mathrm{p} \geq 0.05$; Tabel 5).

\section{Pembahasan}

Karakteristik sampel berdasar atas jenis kelamin didapatkan nilai $\mathrm{p}=1,000$ yang berarti tidak ada perbedaan yang bermakna jenis kelamin antara kelompok norepinefrin dengan plasebo dan kelompok norepinefrin dengan vasopresin.

Karakteristik subjek berdasar atas usia didapatkan nilai $\mathrm{p}=0,647$ yang berarti tidak didapatkan perbedaaan bermakna variasi usia antara kelompok norepinefrin dengan plasebo dan kelompok norepinefrin dengan vasopresin. Karakteristik sampel berdasar atas berat badan didapatkan nilai $\mathrm{p}=0,944$ berarti tidak ada perbedaan yang bermakna berat badan antara kelompok norepinefrin dengan plasebo dan kelompok norepinefrin dengan vasopresin.

Hasil data dasar diketahui bahwa karakteristik sampel terhadap jenis kelamin, usia, dan berat badan tidak didapatkan perbedaan bermakna antara kedua kelompok. Hal ini menandakan kelompok norepinefrin dengan plasebo dan kelompok norepinefrin dengan vasopresin homogen sehingga layak untuk dibandingkan.

Pada penelitian ini, kadar laktat rata-rata pada kelompok norepinefrin dengan plasebo mengalami penurunan pada waktu MAP tercapai target $65 \mathrm{mmHg}$ dengan pemberian norepinefrin dan pada waktu 6 jam setelah pemberian plasebo. Secara statistik penurunan kadar laktat pada waktu MAP tercapai target $65 \mathrm{mmHg}$ dengan pemberian norepinefrin dibanding dengan waktu pasien setelah diberikan cairan $30 \mathrm{~mL} / \mathrm{kgBB}$ didapatkan bermakna $(p<0,001)$. Penurunan kadar laktat setelah 6 jam pemberian plasebo dibanding dengan waktu MAP tercapai target $65 \mathrm{mmhg}$ dengan pemberian norepinefrin secara statistik berbeda bermakna $(p<0,001)$.

Dari analisis data kelompok norepinefrin dengan plasebo dan kelompok norepinefrin dengan vasopresin menunjukkan tidak ada perbedaan penurunan kadar laktat pada pengamatan sebelum perlakuan dengan sesudah target MAP tercapai $65 \mathrm{mmHg}$ dengan pemberian norepinefrin, pada waktu sebelum perlakuan dibanding dengan sesudah pemberian vasopresin dan sesudah tercapai target MAP 65 mmhg dengan pemberian norepinefrin $(p \geq 0,05)$.

Suatu penelitian yang membandingkan penggunaan monoterapi norepinefrin dengan adjuvan vasopresin pada 130 pasien syok sepsis menunjukkan laktat 6 jam pascapemberian monoterapi norepinefrin dengan adjuvan vasopresin tidak berbeda bermakna $(p \geq 0,05)$. Norepinefrin monoterapi tidak inferior dibanding dengan adjuvan vasopresin, tetapi penelitian ini terbatas karena sampel merupakan pasien kritis yang terbatas untuk penelitian dan dipengaruhi oleh penyakit kronik sehingga kesulitan menentukan atau menyeragamkan waktu optimal untuk mulai pemberian. Sekresi vasopresin endogen menunjukkan respons bipasik pada syok sepsis. Vasopresin relatif tidak meningkat sampai 36 jam setelah onset syok septik. Uji klinis inisiasi awal vasopresin $(<12$ jam dari timbul syok septik) menunjukkan efek penghambat pelepasan dan meningkatkan katekolamin sehingga pada pemberian vasopresin harus dipertimbangkan kondisi klinis pasien khususnya perkembangan syok septik. $^{12}$

\section{Simpulan}

Berdasar atas penelitian dapat disimpulkan bahwa penggunaan norepinefrin dengan 
plasebo dan norepinefrin dengan vasopresin, keduanya menunjukkan penurunan kadar laktat yang tidak berbeda. Penelitian ini dapat digunakan sebagai bahan pertimbangan memberikan informasi kepada pasien bahwa norepinefrin maupun vasopresin memiliki pengaruh terhadap penurunan kadar laktat serum.

\section{Daftar Pustaka}

1. Andersen LW, Mackenhauer J, Roberts JC, Berg KM, Cocchi MN, Donninq MW. Etiology and therapeutic approach to elevated lactate levels. Mayo Clinic. 2013;88(10):1127-40.

2. Passarella S, Paventi G, Pizzuto R. The mitochondrial l-lactate dehydrogenase affair. Frontiers Neuro Sci. 2014;8(407):14.

3. Butterworth IV JF, Mackey DC, Wasnick JD, penyunting. Morgan \& Mikhail's clinical anesthesiology. Edisi ke-5. United State of America: McGraw Hill Education; 2013.

4. Heyland DK, Novak F, Drover JW, Jain M, Su X, Suchner U. Should immunonutrition become routine in critically ill patients. J Am Anesthesiol Med. 2008;286(8):94453.

5. Barzegar E, Ahmadi A, Mousavi S, Nouri $M$, Mojtahedzadeh $M$. The therapeutic role of vasopressin on improving lactate clearance during and after vasogenic shock: microcirculation, is it the black box?. Acta Med Iranica. 2016;54(1):15-23.
6. Tan J, Chen H, Chen X, Zhang D, He F. Vasopressin and its analog terlipressin versus norepinephrine in the treatment of septic shock: a meta-analysis. Int J Clin Exp Med. 2016;9(7):14183-90.

7. Dellinger RP, Levy MM, Rhodes A, Annane D, Gerlach H, Opal SM, dkk. Surviving sepsis campaign international guideline for severe sepsis and septic shock. Crit Care Med. 2013;41(2):580-637.

8. Russell JA, Walley KR, Singer J, Gordon AC, Hébert PC, Cooper J, dkk. Vasopressin versus norepinephrine infusion in patients with septic shock. N Eng J Med. 2008;358(9):877-87.

9. Weismuller K, Weigand MA, Hoffer S. The neuroendocrine axis: the nervous system and inflammation. Ann Update Intens Care Emerg. 2012;2012(3);12-6.

10. Zhou FH, Song Q. Clinical trials comparing norepinephrine with vasopressin in patient with septic shock: a meta-analysis. Mil Med Res. 2014;1(1):1-6.

11. Elamin M, Camporesi E. Evidence-based nutritional support in the intensive care unit. Int Anestesiol Clin. 2009;47(1):12138.

12. Daley MJ, Lat I, Mieure KD, Jennings HR, Hall JB, Kress JP. A comparison of initial monotherapy with norepinephrine versus vasopressin for resuscitation in septic shock. Ann Pharmacother. 2013;47(3):301-10.

13. Annane D, Bellissant E, Cavaillon JM. Mechanism of septic shock. Lancet. 2007;365(9453):63-78. 